\title{
Kombinirani izborni sustavi u Europi 1945. - 2014. godine. Parne komparacije Njemačke $i$ Italije, Bugarske i Hrvatske
}

Plejada, 2014., 352. str.

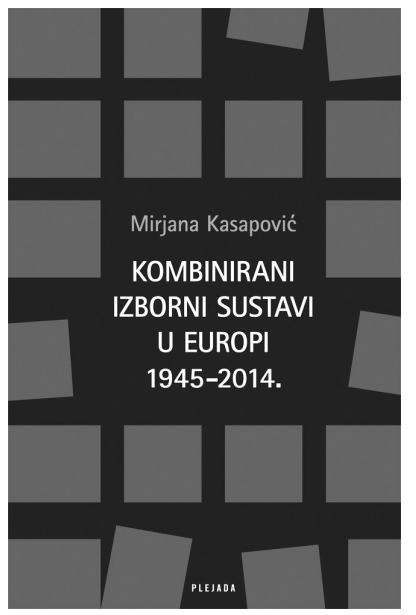

U vrijeme kada je medijski aktualna priča oko hrvatskoga izbornoga zakonodavstva i možebitnoga referenduma o tome pitanju nova znanstvena knjiga Mirjane Kasapović, koja se dotiče i te teme, mogla bi i trebala bi biti zanimljiva i poučna za mnoge u hrvatskom društvu.

Gore navedeno djelo u izdanju Plejade, sve respektabilnije izdavačke kuće, strukturirano je u tri veće cjeline, odnosno poglavlja. U prvome se od njih, koji je dijelom prošireni prethodno već objavljeni članak, temeljito analizira pojam kombiniranih izbornih sustava i iznosi što su uopće jesu. Odgovor na pitanje nije nimalo jednostavan, što je jasno već iz statističkog navođenja gdje sve takav sustav postoji u svijetu, a što se pak od autora do autora razlikuje. S druge strane, precizno nabrajanje država koje su imale kombinirani sustav interpretacijski je, vidjet ćemo i kasnije, opravdano jer je „većinom riječ o državama koje su [takav sustav] institucionalizirale devedesetih godina 20. stoljeća u sklopu transformacije autokratskih u demokratske političke poretke“ (str. 26). Autorica zatim naznačuje koncepte i tipologije kombiniranih izbornih sustava, navodeći strukturni pristup kao nezadovoljavajući jer u njemu - osim toga da se sastoje od nekog vida većinskog i razmjernog obrasca te proizvoljnog određivanja minimalne zastupljenosti pojedinoga obrasca, pri čemu se navode mnogi podtipovi tome - „ništa više nije rečeno o njihovim konstitutivnim svojstvima“ (str. 38). Iznosi i analitički pristup Shugarta i Wattenberga, čija je primarna odrednica postojanje dviju strukturno različitih razina (listovne i nominalne) na kojima se glasa i na kojima se raspodjeljuju mandati, no smatra nedostatkom to što nisu jasno spomenuli institut glasovanja s dva glasa (jedan glas na listovnoj, drugi na nominalnoj razini) kao drugi nužni element kombiniranih izbornih sustava, a koji omogućuje brojne inačice strateškog ponašanja glasača na biralištu. Treći je nužan element, navest će ona kasnije, postojanje različitih obrazaca „izbora političkih predstavnika u isto predstavničko tijelo“ i potencijalni nastanak „dviju vrsta zakonodavaca“ (str. 73), pri čemu se misli na njihovu različitu 
usmjerenost u radu i odgovornost prema različitom biračkom tijelu, ovisno već o tome na kojoj su listi stekli mandat. Sve to kumulativno stvara „nov i složeniji okvir za izbornu utakmicu“ i različite učinke u odnosu na većinski ili razmjerni sustav i opravdava, smatra argumentirano autorica, vrednovanje kombiniranog izbornog sustava kao zasebnog sustava, a ne nečega što bi nužno bilo između većinskog i razmjernog. Autorica iznosi i brojne druge poteškoće oko podjele kombiniranog izbornog sustava na podtipove - mnoga rješenja, ali i njihove kritike. Zdrava kritika, osim što ju je zanimljivo čitati, nešto je što itekako nedostaje našoj znanosti, koja se često svodi na nekontekstualno prepisivanje arhiva, nizanje statistika, prepričavanje što su drugi rekli i sl., ovisno već o kojem je znanstvenom polju društvenih i humanističkih znanosti riječ. Autorica navodi kako je i kada u pojedinim zemljama došlo do kombiniranog izbornog sustava, još od Portugala na kraju 19. stoljeća, Danske, Islanda i Mađarske na početku 20. stoljeća pa, detaljnije, sve do obrazaca nastanka suvremenih kombiniranih izbornih sustava (s iznimkom Njemačke, od devedestih godina 20. stoljeća naovamo), pri čemu ih dijeli na one koji su nastali kao rezultat kompromisa: stranke na vlasti i opozicije (Mađarska, Bugarska, Albanija), unutar vladajućeg bloka (Jugoslavija, Hrvatska, Litva), glavnih aktera u sustavu vlasti (Rusija, Ukrajina, Makedonija), dviju glavnih političkih stranaka (Njemačka), etabliranih stranaka i aktera civilnog društva (Italija). Zanimljivo je u tom kontekstu spomenuti da je ista autorica ipak svojedobno iznosila na str. 8 knjige Izborni i stranački sustav Republike Hrvatske 1993. da „[U]poraba izraza 'izborni model' nije slučajna. U ovom se sklopu on koristi umjesto izraza 'izborni sustav"“, navodeći da su izbori 1992. godine provedeni „prema izbornom modelu koji je bio spoj dvaju različitih tipova izbornih sustava. Tim spajanjem nije nastao novi izborni sustav, nego poseban izborni model“. Termin model autorica rabi i u naslovu jednoga (u ovom djelu u bibliografiji neuvrštenoga) članka o segmentiranim izbornim sustavima/modelima u časopisu Politička misao u br. 1. godine 1995. Nije to sve ni bilo potrebno spominjati u knjizi o kojoj govorimo, pa nije naša namjera reći da autorica nešto skriva. Dapače, to ističemo i kao pohvalu jer ukoliko nas dokazi uvjeravaju da nismo u pravu, mišljenje je uvijek potrebno i promijeniti.

Drugo je poglavlje najopsežnije te se u svakome od četiri potpoglavlja detaljnije analizira izborni sustav jedne zemlje. Redom su to Njemačka, Italija, Bugarska i Hrvatska. Sve su to države koje su u svojoj nedavnoj povijesti imale (Italija, Bugarska, Hrvatska) ili imaju (Njemački) kombinirani izborni sustav. Premda se usredotočuje na razdoblje od 1945. godine naovamo, dakako da svaka od tih država ima svoju specifičnu povijest, pa samim time postoje i razlozi zbog čega se u nekom trenutku odlučilo za određeni izbori sustav, odnosno zbog čega ga se pak napustilo. Autorica navodi razloge zbog kojih je koja od zemalja pristupila kombiniranom izbornom sustavu (ugrubo rečeno: Njemačka je nakon poraza u Drugom svjetskom ratu postala svjesna da je jedna od varijabli koje su kumovale usponu Hitlera na vlast bio čisti razmjerni sustav; Italija je nakon urušavanja političkih stranaka ogrezlih u mnoge korupcijske afere 1990-ih godina shvatila da je potrebno mijenjati i izborni sustav, a Bugarska i Hrvatska to su učinile nakon urušavanja komunizma, suočene s tranzicijskim, a i nekim drugim vlastitim specifičnostima). Dakako, nemoguće je ovdje ukratko iznijeti kakav je kombinirani izborni sustav bio ili jest na snazi u Italiji od 1993. do 2006. godine, u Njemačkoj od 1953. do danas itd. (samo je postupak raspodjele 
mandata u Njemačkoj, donijet 2013. godine nakon mišljenja Ustavnog suda, prikazan u knjizi na više od dvije stranice - str. 116-118). I u jednom i u drugom slučaju riječ je o u nekoliko rečenica neopisivoj matematičkoj metodi preračunavanja glasova u mandate i međuutjecaju nominalnih i listovnih razina, koje su u talijanskom slučaju, zbog tzv. scorpora (tj. odbijanja glasova), imale i zanimljive makinacijske učinke u vidu isticanja, od strane određenih političkih opcija, izmišljenih lista s kojima su se povezivali kandidati u jednomandatnim okruzima (str. 145 i 148). Takvo što poprimilo je u Albaniji još grotesknije razmjere, što autorica potanko opisuje (str. 260-263). U Njemačkoj se još sredinom prošloga stoljeća stranački sustav oblikovao kao dvostranački i dvoipolstranački, da bi tek od osamdesetih krenuo proces fragmentacije. U Italiji, zbog niza razloga, kombinirani izborni sustav nije polučio učinke smanjenja fragmentacije stranačkog sustava, ali je omogućio češću smjenjivost vlasti, kao i veću stabilnost (str. 147-156). U Hrvatskoj je kombinirani izborni sustav u svojim dijelovima proizveo učinke koji se pripisuju razmjernom, odnosno većinskom segmentu posebno. No taj je sustav, posebno 1992. godine, u svom tada dominantnom - većinskom - dijelu izlučio nesposobnu opoziciju koja nije isticala zajedničkog kandidata i nije se založila za dvokružne izbore u tom segmentu. To je imalo za učinak sustav s dominantnom strankom, a ne, kao što bi se možda očekivalo u sličnim okolnostima negdje drugdje, dvostranački sustav.

Treće poglavlje knjige započinje argumentiranim teorijskim utemeljenjem pristupa parne komparacije kojem je autorica prionula. Zatim se uspoređuju kombinirani izborni sustav i njegovi učinci u Njemačkoj (s centrifugalnim izbornim obrascem - str. 235-238) i Italiji (s centripetalnim izbornim obrascem - str. 238-241) te u Hrvatskoj i Bugarskoj. Što se tiče potonje usporedbe, u Bugarskoj, a što je važno za strukturiranje stranačkog sustava, „nije bilo jasnih i stabilnih rascjepa koji bi determinirali trajniju stranačku strukturu“ (str. 243), dok se u Hrvatskoj struktura društvenih rascjepa oblikovala početkom devedesetih godina prošloga stoljeća i ostala stabilna više od 20 godina (str. 245). Kao drugo, u Bugarskoj je bilo prisutno „blokovsko organiziranje političke opozicije“ (str. 245), dok su u Hrvatskoj, s iznimkom prve polovine 1990-ih, „glavni stupovi stranačkog sustava“ (str. 246) bili HDZ i SDP. Zaključuje se kako su politički akteri „utjecali na strukturu i prirodu društvenih rascjepa“ (str. 249) produbljujući ili pak ublažavajući postojeće rascjepe te možebitno potičući ili potiskujući one nove, kao i o tome da su isti ti akteri „mijenjali očekivane učinke izbornih sustava primjernom različitih strategija djelovanja“ (str. 249), uključujući i izigravanje izbornih pravila, što su omogućila izborna pravila u kombinaciji sustava glasovanja s dva glasa (npr. u Italiji i Albaniji). U zaključnom se razmatranju tako još iznose i neki primjeri, kao oni iz Rusije i Ukrajine, gdje je većinski segment kombiniranog izbornog sustava rezultirao proliferacijom neovisnih kandidata - dakako ne zbog većinskog sustava samog po sebi (postoje i suprotni primjeri), već zbog konteksta u kojemu se politički proces odvijao. Sve u svemu, i to je jedan od argumenata kojima se pokazuje ključna teza knjige - kombinirani izborni sustav, uz ostalo i svojim institutom glasovanja s dva glasa, omogućujući tako cijepanje glasova, može proizvesti vlastite političke učinke, različite od učinaka razmjernog ili većinskog sustava zasebno. Politički izbori i ponašanje birača na njima uvijek su jedna vrsta kompleksnog sustava, kako to na istom primjeru jasno pokazuje Philip Ball u knjizi Kritična masa. Autorica to ne kazuje izrijekom poput Balla, ali sadržajno poručuje 
upravo isto. Završava knjigu time da se „do jednakih [...] konačnih rezultata“, neovisno je li riječ o nečemu planiranom ili neplaniranom u odnosu na ciljeve, „može doći različitim putevima“ (str. 265).

Iako je knjiga u prvom redu vrijedno znanstveno djelo, mogu je čitati i razumjeti i oni kojima politologija nije struka, a zanima ih tematika kojom se autorica bavi. No vrijedi u ovom kontekstu istaknuti dvije stvari. Prvo, čitatelji jednostavno zbog teme o kojoj je riječ (što jednako vrijedi i za one kojima je politologija struka i za one kojima to pak nije) ipak moraju na pojedinim mjestima biti vrlo koncentrirani ukoliko žele sasvim shvatiti neka pitanja (npr. kad se govori o trenutnom načinu raspodjele mandata u Njemačkoj na str. 116-118 itd.). Oni koji imaju odbojnost prema matematici neće možda stoga doći na svoje, no za to su ipak sami krivi. Drugo, ako već nije bilo razloga da to učini Mirjana Kasapović, ne bi bilo naodmet da je - želi li se proširiti krug čitatelja - urednik knjige manje poznate pojmove objasnio ili u bilješkama ispod teksta ili u nekom posebnom rječniku na kraju knjige. Odnosi se to na neke pojmove kojima se barata (npr. efektivan broj stranaka, indeks nerazmjernosti - autorica korektno navodi gdje se nalazi obrazac izračuna navedenoga (str. 31)), a čije definicije netko izvan znanstvenih krugova ne poznaje. No odnosi se to ponegdje i na naziv određenog izbornog sustava, naziv metode preračunavanja glasova u mandate, ali i niz drugih termina (npr. koja je, prilikom govora o vrstama lista, razlika fleksibilne, otvorene i kvaziliste - str. 39). Zbog svega bi toga za nekoga kome politologija nije struka ipak bilo korisno da prilikom čitanja pri ruci ima autoričin 2003. godine objavljeni Izborni leksikon. Pogotovo bi takvo što bilo korisno onima koji u hrvatskom medijskom prostoru tumače svoje jednim dijelom ipak korisne i suvisle prijedloge za promjenom izbornog zakonodavstva (što ne znači da takvi prijedlozi ne mogu biti još korisniji i suvisliji). ${ }^{1}$

Djelo donosi zavidnu bibliografiju (str. 269-332), s navodima mnogih recentnih djela. Osim toga, oni čiji se interesi u prvom redu ne tiču izravno izbornih sustava zemalja koje autorica navodi, već ih zanima nešto drugo o političkom sustavu dotične zemlje, također bi mogli posegnuti za knjigom. Naime autorica često u bilješkama donosi relevantnu a i recentnu literaturu ne samo o užoj temi izbornih sustava i nekih njihovih elemenata već i o nekim povijesnim razdobljima o kojima govori, o političkim sustavima, o strankama itd., a sve to počesto i s dvoznamenkastim brojem bibliografskih jedinica (npr. o Weimarskoj Republici, posebnosti njemačkog puta u

1 U takvim istupima često vlada terminološka zbrka pa se nešto što je zatvorena neblokirana lista (naspram zatvorene blokirane liste, koja je sada na snazi), naziva pulotvorenom ili otvorenom listom, o čemu se svatko može uvjeriti pretražujući internet i nalazeći u tom kontekstu i izjave Mate Arlovića iz 2003. godine te Vladimira Šeksa i Radimira Čačića iz 2014. Dakako, da se stvari nazovu pravim imenom i da se vidi da, npr., inicijativa U ime obitelji spominje zatvorene neblokirane liste (gdje se glas može dati samo pojedincima s liste za koju se glasovalo) kao referendumsku temu, a nikako ne i otvorene liste (gdje se glas može dati i pojedincima s različitih stranačkih, koalicijskih i neovisnih lista) - prosječan bi se građanin sigurno zapitao što je to onda otvorena lista i zašto se nju u raspravi uopće ne spominje (ovdje ipak ne plediramo za ovaj ili onaj izborni sustav, svjesni k tome činjenica da i otvorene liste imaju svoje mane). 
demokraciju, povijesti razvoju političkih stranaka u promatranim zemljama i sl., pri čemu je zgodno konzultirati literaturu i o hrvatskim povijesnim temama, gdje postoje neke i ne baš poznate knjige koje su tu i tamo citirane, kao npr. Čuvalova knjiga o Hrvatskom proljeću itd.), što je čitatelju izvrsno polazište za daljnje istraživanje. No o daljoj povijesti izbora u Hrvatskoj malo je pisano, pa je šteta što knjiga Totalna predstavljenost - neovisno o tome što je u svojoj biti prilično loša - Ive Škrabala i Aharona Nathana nije spomenuta barem u dijelu o povijesti izbora u Hrvatskoj do 1990. godine, ako već to nije bio slučaj s onom više povijesnom i autorici nepoznatijom literaturom, kao što je npr. djelo Jasne Turkalj o pravaškom pokretu 1878. - 1887. godine. Kako god, povijest izbornog zakonodavstva u Hrvatskoj ostaje zanimljivo područje za daljnje istraživanje, više povjesničarima nego politolozima.

Valja se kritički osvrnuti na sam naslov knjige koja, premda tiskana na početku 2014. godine (predgovor, koji se najčešće piše na kraju, autorica je napisala u siječnju dotične godine), naslovom želi poručiti kako će se obraditi razdoblje do 31. prosinca 2014. godine, dakle ono što se u vrijeme tiskanja još nije dogodilo. Bez obzira na marketinške želje izdavača, takvo što ipak se ne bi smjelo događati. Kronološki posljednje što autorica opisuje jesu okolnosti bugarskog povratka na razmjerni sustav u izborima u svibnju 2013. godine, no ne spominje mišljenje talijanskoga Ustavnoga suda koji je u prosincu 2013. tamošnji de facto premijski izborni sustav (na snazi od 2006. godine) - na osnovi kojega lista s najviše glasova automatski osvaja 340 od 630 mjesta - proglasio neustavnim (http://www.reuters.com/article/2013/12/04/ us-italy-law-unconstitutional-idUSBRE9B30YW20131204). Mirjana Kasapović to kao znanstvenica sigurno ne bi propustila spomenuti, pa je očigledno da je ovo djelo - koje izlaže o nečemu vrlo živom, dinamičnom, aktualnom i podložnom čestim promjenama, kako navedeni primjer pokazuje - već tada bilo u procesu za tisak. Međutim, bez obzira na navedeno, nepreciznom naslovu (koji bi takav, s obzirom na talijanski primjer, bio čak i da je 2013. godina uzeta kao dolazna točka) i onome tko je za njega sve kriv, valja uputiti dobronamjernu kritiku.

U knjizi se potkradaju i neki teško shvatljivi vidljivi lapsusi ili druge manje vidljive netočnosti i nedosljednosti, dio kojih svakako ide na dušu i recenzentima Čularu i Zakošeku. Tako ispada da Hrvatska „nije bila samostalna država“ u razdoblju „do 1992.“ kada je bila „u sastavu [...] Jugoslavije“, premda je iz konteksta jasno da se tako ne misli (str. 191). Vojna krajina pripojena je Kraljevini Hrvatskoj i Slavoniji 1881., a ne 1882. godine (str. 191). U tablici 7. (str. 102) netočno je navedeno da je razina pretvaranja glasova u mandate u Njemačkoj 1953. bila pokrajinska, iako je već tada bila savezna, što je jasno i iz teksta (str. 99), za razliku od 1949. godine. Ako i oprostimo takve očite ili manje očite lapsuse, kakvi se uvijek potkradu i u najpomnije pisanim i pripremanim knjigama, kao i one, npr., na dnu okvira 4. (str. 221) u primjeru drugog postupka dijeljenja (gdje je ispalo da je 350 000/10 $000=3,5$ ); kao i to da je npr. prilikom govora o izborima 1990-ih u RH jedna lista malo nazivana Riječkim demokratskim savezom (RDS) (str. 215), a malo Demokratskim savezom Rijeka (DSR) (str. 215 i 223) te da se prilikom navođenja literature autorica na str. 222 trebala pozvati na „Kasapović 2011.a“, a ne na „Kasapović 2011.“; da se na str. 253 trebala pozvati na „grafikon 5.“, a ne na „grafikon 4.“; kao i na str. 153 u govoru o učincima kombiniranog sustava u Italiji reći da „prvi cilj nije bio ostvaren“, a ne 
„drugi“ itd. - ima ipak takvih previda za koje jednostavno ne znamo kako je do njih došlo. Tako tablica 24. o nominalnom i efektivnom broju stranaka u parlamentima Bugarske i Hrvatske (str. 247) ima poveći broj netočnosti i nedosljednosti, što je vidljivo usporedbom s onim što je bilo napisano u dotadašnjem tekstu. Postoje i jezične nezgrapnosti, kao kad se „to jest“ rabi kao sastavni veznik u govoru o Acerbovu zakonu, pa iz rečenice proizlazi da relativna većina automatski znači osvojenih 25\% glasova (str. 129), što dakako da nije točno - za dobiti $2 / 3$ mjesta prema dotičnom zakonu trebalo je osvojiti relativnu većinu, koja je ujedno i minimalno 25\% osvojenih glasova. Metodološki nije baš najsretnije kad se neka povijest (kao u slučaju talijanskoga stranačkoga sustava i talijanskih vlada - str. 136) podijeli kronološki na četiri faze, pa se između pojedinih faza dotične podjele nalaze vremenski vakuumi od po nekoliko godina. Ne bi bilo zgorega da se objasnila i specifičnost regije Dolina Aoste te navelo kako se ona očitovala u konkretnim okolnostima. Primjerice, nejasno je tako kako su zapravo glasovali birači te male regije za vrijeme kombiniranog izbornog sustava (str. 142-143) i zbog čega baš ona ima specifičnu ulogu u premijskom sustavu (str. 158-159). A i 340 mjesta u Predstavničkom domu u Italiji nije isto što i $55 \%$ (str. 158), što je sve dio teme o prethodno spomenutoj regijici. Također, teško da je u Bugarskoj, kad se 1990. godine u razmjernom segmentu biralo 200 zastupnika u 31 okrugu „prosječne veličine 7,7“ (još jedan previd: 31 pomnoženo sa 7,7 daje 238,7; a iz iduće se rečenice o granicama okruga možda može prilično vjerojatno, pri čemu to nije matematičko nužno, zaključiti o postojanju 32 okruga; prosječna je veličina dakle po svemu sudeći nešto manja od 7 zastupnika po okrugu) nekontroliranu proliferaciju parlamentarnih stranaka spriječio zakonski prag od četiri posto (str. 182), to je učinio sustav malih okruga u kombinaciji s D'Hondtovom metodom tvoreći sam po sebi prirodni prag prilično veći od četiri posto. No bez obzira na sve navedeno, ovu knjigu, koja zaista kao prvorazredno znanstveno djelo zaslužuje najvišu ocjenu, možemo preporučiti za čitanje.

\section{Ivan Tomljenović}

